\title{
ON COSTA VARIATION IN LEAVES OF FOSSIL PERMIAN PROTOSHAGNALEAN MOSSES
}

\section{ОБ ИЗМЕНЧИВОСТИ ЖИЛКИ В ЛИСТЬЯХ ПРОТОСФАГНОВЫХ МХОВ ПЕРМСКОГО ПЕРИОДА}

\author{
ELENA V. MASLOVA ${ }^{1} \&$ MichAEL S. IGNATOV ${ }^{2}$ \\ ЕЛЕНА В. МАСЛОВА ${ }^{1}$, МИХАИЛ С. ИГНАТОВ 2
}

Abstract

Leaves of extinct mosses of the order Protosphagnales are studied with the special attention to their different developmental stages. A previously unknown morphotypes without costa and with very short costa are revealed in this group. It is characteristic for young small leaves of Kosjunia and Intia, but apparently does not occur in other genera of this fossil order. The present collection allows restore a heteroblastic series in these leaves and associated with it differentiation of laminal areolation.

Резюме

Изучены листья на разных стадиях развития у верхнепалеозойских мхов порядка Protosphagnales. Выявлен ранее неизвестный тип строения листа с короткой и даже полностью отсутствующей жилкой у мелких молодых листьев, который характерен для родов Kosjunia и Intia variabilis и, по-видимому, не встречался у других родов протосфагновых мхов. Имеющиеся остатки позволяют реконструировать гетеробластические серии развития листьев и дифференциации их клеточной сети.

KEYWORDS: fossils, Intia, leaf morphogenesis, heteroblastic series, mosses, Paleozoic, Permian, Protosphagnales

\section{INTRODUCTION}

No less that $2 / 3$ of extant mosses have leaves with a strong single costa. It is present in acrocarpous groups with only a limited number of exceptions (Hedwigia, Gigaspermum, Erpodium, Rhacocarpus, Schistostega and few others). In pleurocarpous mosses the strong reduction of costa up to short and double state, as in Hypnum, or more rarely complete absence, as in Leucodon, is found in about a half of species, as can be roughly estimated from different floras and general classification (Frey \& Stech, 2009; Goffinet et al., 2009).

In Paleozoic mosses, a strong single costa disappearing shortly below leaf apex is known in almost all species that are structurally preserved (Amaral et al., 2004; Anderson \& Anderson, 1985; Chandra, 1995; Christiano de Souza et al., 2012; Ignatov, 1990, 2013; Ignatov \& Shcherbakov, 2009; Meyen \& Gomankov, 1987; Lacey et al., 1975; Smoot \& Taylor, 1986; Thomas, 1972), and in Protospagnalean mosses in particular (Neuburg, 1960; Fefilova, 1978; Maslova et al., 2012a; Meyen \& Gomankov, 1987). The only exception is Muscites amplexifolius Ottone \& Archangelsky from Carboniferous of Argentina (Ottone \& Archangelsky 2001); however, the absence of costa in this species and large isodiametric cells ca. $50 \mu \mathrm{m}$ in diameter are more characteristic for hepatics than mosses (Ignatov, 2013).
All earlier descriptions of Protospagnalean mosses indicate the presence of costa almost to leaf apex (Neuburg, 1960; Fefilova, 1978; Meyen \& Gomankov, 1987; Ignatov, 1990). Percurrent costa was reported as well, but this case was never illustrated by Fefilova (1978). Neuburg reported this rare case only once: one of her figures of $I$. vermicularis illustrates dark area (a cell row of one cell wide?) linking the costa end and strong border (Neuburg, 1960: Fig. 3,3). It is very likely that its interpretation as a percurrent costa is correct, although alternative explanation as an artefact can not be totally rejected.

Costa characters were used by Fefilova (1978) as a diagnostic for separation e.g. Uskatia dentata (costa percurrent) from $U$. conferta (costa disappearing below apex), I. variabilis (costa forked at its end) from I. vicaria (not forked), Kosjunia retusa (costa ending abruptly) from $K$. polyedra (gradually thinning towards its end).

In the study of a collection from Adzva locality, a number of leaves at different stages of development were found. Some of them were discussed and illustrated by Maslova et al. (2012a), along with the discussion on leaf development. That study was concentrated on distribution of actively dividing cell zones within the leaf, which are not similar to the known patterns in extant mosses, the latter being so invariable throughout all the moss groups (Frey, 1971). 
Additional collections brought another interesting observation on structural difference never described earlier for Paleozoic mosses. Some leaves were found to have a very short costa or even lack of costa at all. These are mostly smaller and obviously younger leaves, providing a certain problem for identification, especially if we consider cases of enormous variation within a single leaf, where lower and upper parts have characters usually assumed to be diagnostic for genera (Maslova et al., 2012a). Regardless of still incomplete understanding of these fossils and their only preliminary and partial taxonomic identification, this unusual costa variation pattern is specifically addressed and discussed here.

\section{MATERAIL AND METHODS}

The material for the present study was collected from the Pechora Coal Basin, Adzva River by I.A. Ignatiev, Yu.V. Mosseichik, A.P. Vlasov, M.S. Ignatov, O.V. Ivanov, D.G. Donskov and N.Yu. Stepanova (Maslova et al., 2012a). According to Pukhonto (1998) and identifications of vascular plant remains by Ignatiev (mostly Cordaites species), the age of the deposits was determined as Upper Kazanian of the Upper Permian on East European (continental) scale. The studied plant burials were probably formed under conditions of the low, partly waterlogged flood plain. The moss remains occur in the form of mass accumulations gathered together on the bottom of flat hollows, oxbow lakes and pools, which became covered with fine-grained deposits during the floods.

To extract the moss and other plant remains from inorganic matter, the standard bulk-maceration method was used (Andrews, 1961; Darrah, 1960). The fragments of rock were placed into 50\% fluoric acid during 14 days or more, washed and mounted in permanent glyceringelatin slides. The material is kept in the Main Botanical Garden of the Russian Academy of Sciences (Moscow), collection Adzva32. For additional details on locality and methods see Maslova et al. (2012a).

\section{GENERA AND SPECIES IDENTIFICATION}

The circumscription of Protosphagnalean moss structure requires a somewhat broader understanding of leaf variation patterns, which is still in progress. This problem is getting more complicated also due to mostly dispersed fragments available from the bulk maceration, where the mixture of different genera occurs. Therefore, most names are preliminary, having the same state as in Maslova et al. (2012a).

\section{RESULTS}

Altogether 800 large leaf fragments were mounted in slides, studied and photographed, and among them a few tens of young leaves were found. Some of them were illustrated by Maslova et al. (2012a), along with the general discussion on leaf development, and in certain cases species were characterized by a rather complete series of ontogenetic stages: for example, in Intia angustifolia Neuburg (Maslova, 2012a, Figs. 4-8). Most small young leaves in that study have more or less strong costa, while in a few leaves of Kosjunia (Maslova, 2012a, Figs. 38, $51,55)$ the costa was shorter and thinner.

Among new specimens, some leaves were totally ecostate. Two of them were found in attachment to a subapical part of the stem (Fig. 1). Leaves are very small, $200 \times 150 \mu \mathrm{m}$, having the same width with the upper part of the stem. It is not clear enough if an apical cell itself was preserved: an unclearly seen general outline implies its possible presence, but in this case its almost naked state is quite unusual, as typically there are a leafy structures that cover the apical cell more closely.

The uppermost leaf is sitting ca. $100 \mu \mathrm{m}$ below the putative stem apex. The second one (on the right in Fig.1) is attached at ca. $230 \mu \mathrm{m}$ below the apex; it has an attenuate leaf base (similar to that in leaves in Fig. 3). The third leaf is already much more distant, ca. $520 \mu \mathrm{m}$ from the apex (partly seen in Fig. 1). Its preserved part (though likely almost complete) is $450 \mu \mathrm{m}$ long and $140 \mu \mathrm{m}$ wide at base; it has an elongate shape and a distinct costa. The fourth leaf is at $200 \mu \mathrm{m}$ below the third one, (approximately the same distance as between the second and the third ones), and this fact favors that the leaf series on this shoot end is complete. If so, only two smaller leaves are ecostate in this moss. Cells of a proximal part of the third leaf are ca. $20 \times 10 \mu \mathrm{m}$, similar to basal leaf cells of Kosjunia in e.g. Fig. 4.

Additional ecostate leaves are shown in Figs. 2, 5, and nearly ecostate are two leaves in Fig. 3. Among them \#5 is $0.3 \mathrm{~mm}$ wide, \#2 is $0.5 \mathrm{~mm}$, leaves in Fig. 3 are 0.7 $\mathrm{mm}$, and the leaf in Fig. 4 with a very thin costa half way up the leaf is $1 \mathrm{~mm}$ wide. This positive correlation between leaf size and costa development supports the consideration of these specimens as developmental stages, and likely of the same species.

To complete the series, the leaves with maximally similar laminal areolation were selected and shown in Figs. 6-9. Costa is reaching ca. 60\% way upleaf in Fig. 6 or to $75 \%$ in other cases, but at the same time the number of cells between the end of a costa and leaf apex remains approximately the same, 15-20, and this holds true in smaller leaves in Figs. 1-5.

The areolation in upper part of more developed leaves (Figs. 6-9) is generally similar to that in smaller leaves (Figs. 1-5). However, the larger is a leaf, the more 'Protosphagnum-type' areolation is expressed in a basal leaf part, especially in auricules. This 'Protosphagnum-type' areolation appears due to unequal cell division which is characteristic also to Intia, but variously performed in different species and in different parts of leaves (Neuburg, 1960; Maslova et al., 2012a,b). Fefilova (1978) established a separate genus Syrjagia for mosses with the pronounced difference in areolation type from 'Protosphagnum-type' in proximal and 'Intia-type' in distal leaf parts, but the present material shows that a more or less apparent cell dimorphism near leaf base versus its absence or moderate expression above is a feature of most Protosphagnalean mosses (although may be indistict in undeveloped and underdeveloped leaves). 

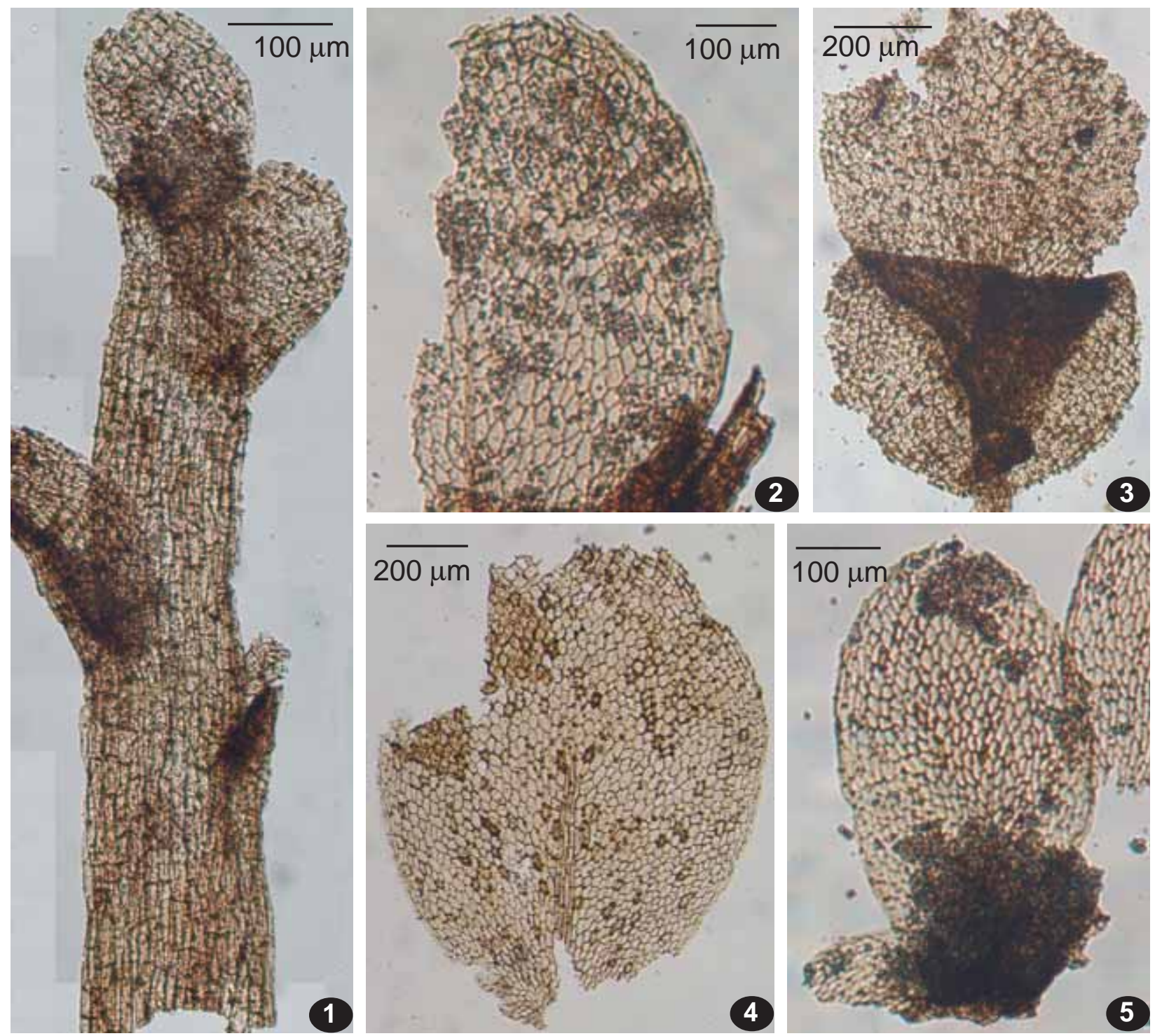

Figs. 1-5. Young leaves of Kosjunia polyedra Fefilova, including shoot with minute leaves (\#1): 1 - 32M_1_12_8; 2 32M_11_27_2; 3-32M_9_3; 4-32M_4_56_1; 5-32M_11_16_4.

Basing on overall similarity of lamina areolation without distinct cell dimorphism, and thin costa disappearing far from leaf apex,we refer leaves shown in Figs. 1-9 to Kosjunia polyedra Fefilova.

The main characters of its leaf development include:

(1) costa is appearing in ontogenesis after the leaf reaches a certain size; (2) cell dimorphism is developing at a later stage and is only moderately expressed; (3) marginal cells are differentiated to limbidium at a late stage, being almost totally identical to laminal cells in the upper part of leaf up to stage shown in Fig. 6.

Although this type of development is not well documented by a more or less complete series of leaves of other species, we may imply its presence in e.g. Intia sp., Figs. 10-11, and Intia vicaria Fefilova, Figs. 12-14. In both cases the costa is rather thin and the border in younger leaves is not (Fig. 10) or poorly (Fig. 14) differentiated. Although the costa is not clearly seen being partly hidden in a lamina fold in Fig. 10, it hardly reaches the leaf middle.
Some other species referred here to the same genus Intia (Figs. 15-20) are characterized by a stronger costa, which appears earlier and is already quite thick in small round leaves. One specimen in Fig. 16, however, lacks a costa, and its similarity in lamina areolation with more developed leaves of I. angustifolia Neub. (Figs. 18, 20, see also Maslova et al., 2012a, Figs. 4-12) indicates rather this affinity than that with ecostate leaves referred here to Kosjunia (Figs. 1-5).

Still a more strong costa occurs in leaves of Vorcutannularia (Figs. 21-26), referred here to two species considering differences in the lamina areolation and the border expression. The genus is characterized by one of the strongest lamina cell dimorphism, appearing at the early stages of development, especially in $V$. laevis Fefilova (Figs. 22, 24, 26). There are no specimens of very young leaves certainly belonging to this genus in our collection, but one leaf in Fig. 21 with a branching costa has a stronger cell dimorphism in its proximal part in 

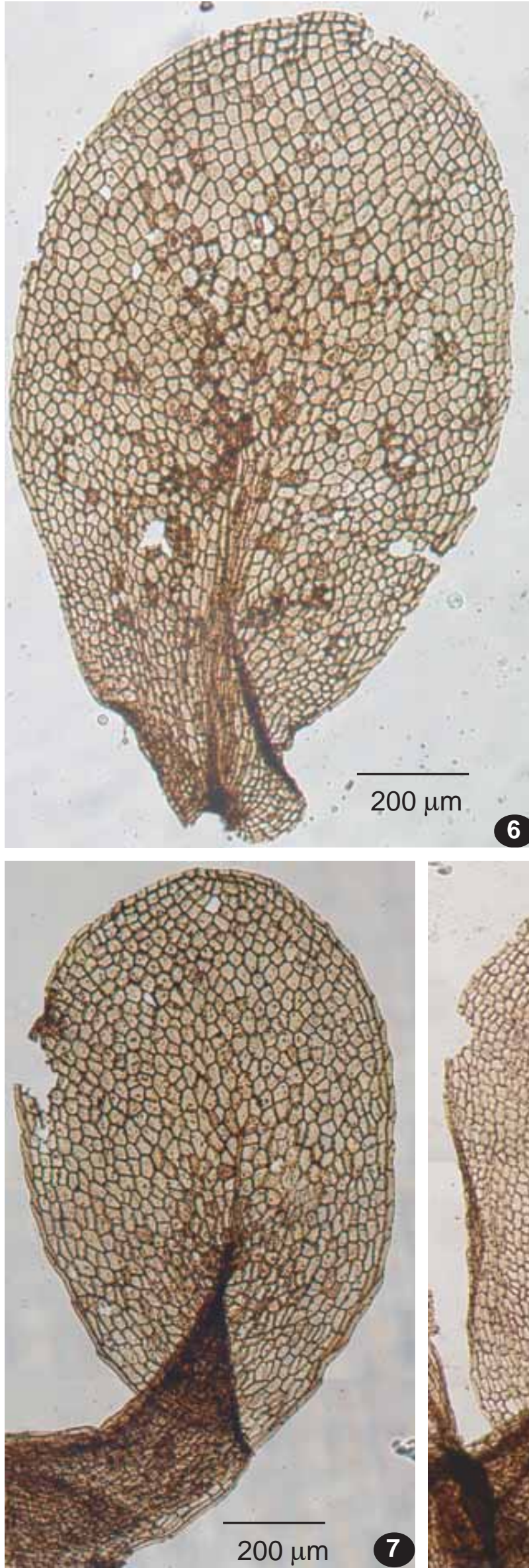


Figs. 6-9. Leaves of Kosjunia polyedra Fefilova at different stages of development: 6 32M $915 \quad 1 ; 7-32 \mathrm{M} 11 \quad 19 \quad 5$; $8-3 \overline{2} \bar{M} 5-96 ; 9-32 \mathrm{M}-\overline{9} \overline{7} 9$ 


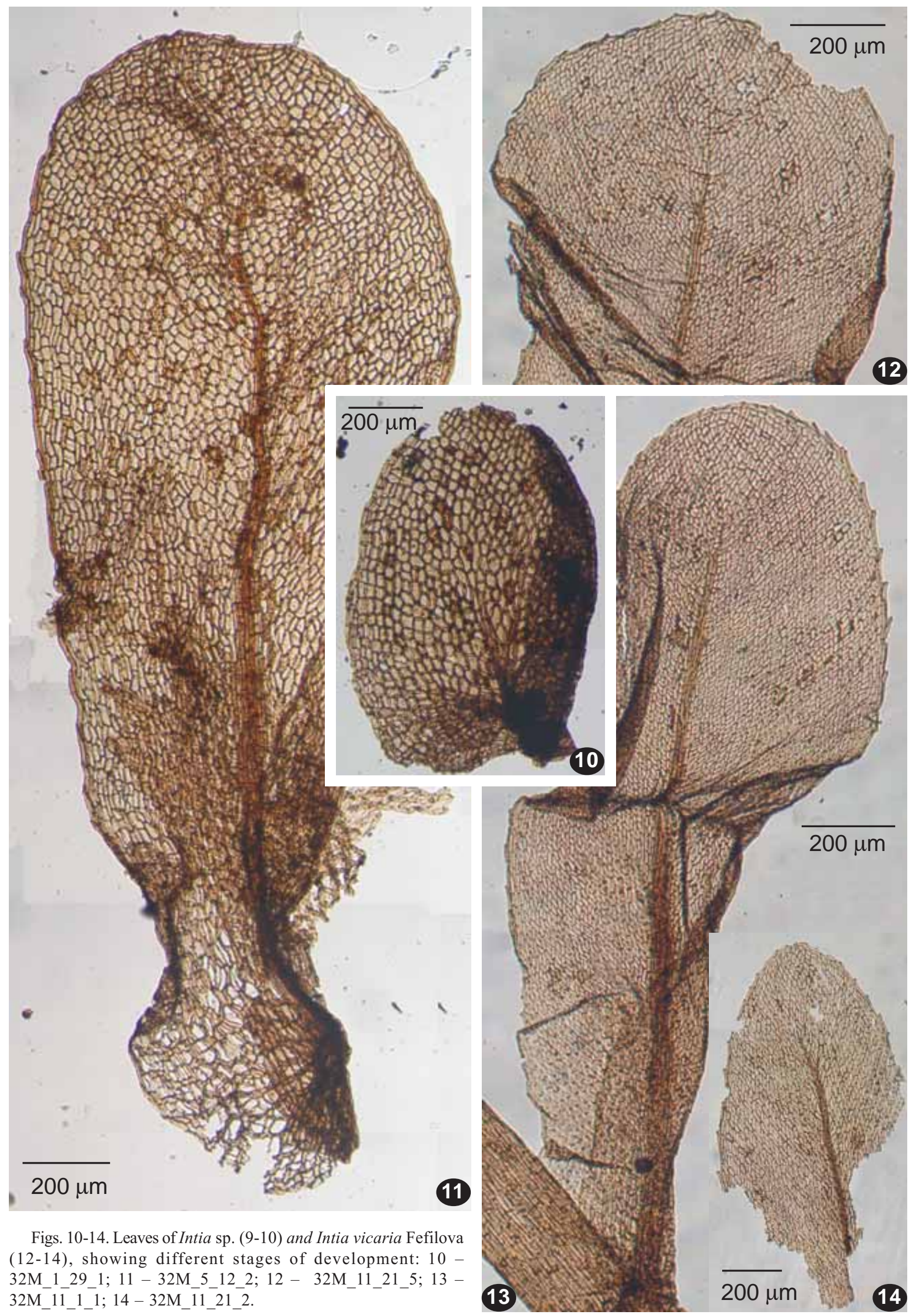



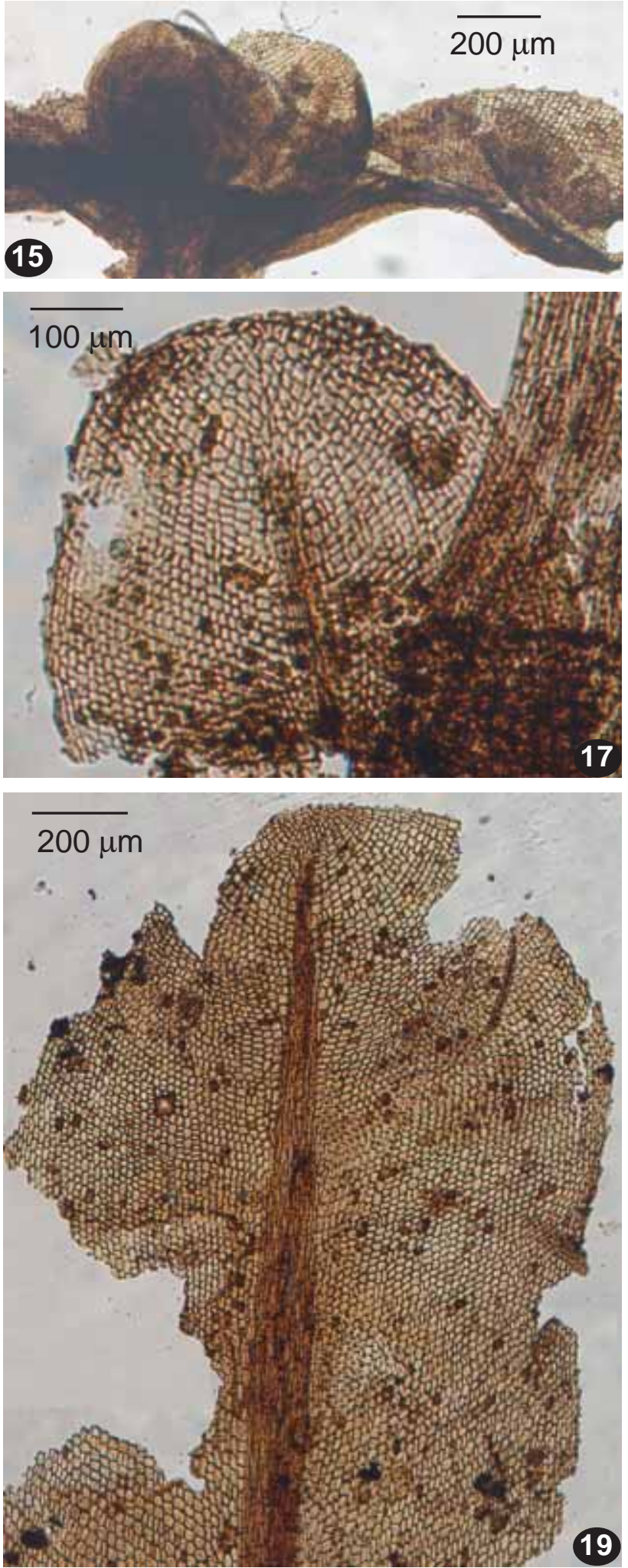

Figs. 15-20. Leaves of Intia variabilis Neub. (?) (15-17) and $I$ angustifolia Neub.(?), showing different stages of development: $15-32 \mathrm{M} 11 \_21 \_2 ; 16-32 \mathrm{M} \_11 \_20 \_4 ; 17-32 \mathrm{M} \_11 \_5 \_1 ; 18$ $-32 \mathrm{M} 11-16 \_1 ; 19-32 \mathrm{M} 11-283 ; 20-32 \mathrm{M} 11-282$.

Figs. 21-26 (page 67). Leaves of Vorcutannularia (?), V. plicata Neub. (?) $(22,25)$ and $V$. laevis Fefilova $(23-24,26): 21-$ $32 \mathrm{M} \quad 9 \quad 23 \quad 4 ; 22-32 \mathrm{M} 118$ 1; 23 - 32M $11 \quad 16 \quad 1 ; 24-$ 32M_1_51_1;25-32M_11_27_4; $26-32 \mathrm{M} \_1$ - $42 \_1$.
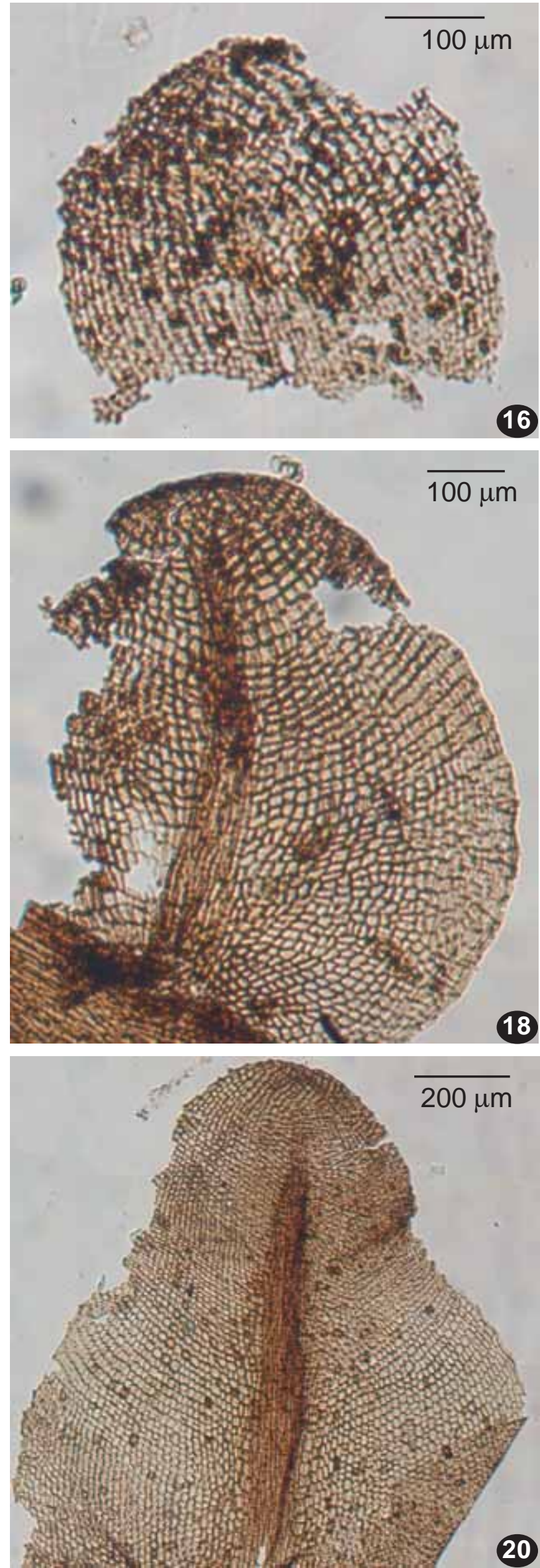


comparison with other leaves of the same size (e.g. Figs.10, 16), that makes its putative placement to this genus to be rather likely.

\section{DISCUSSION}

In extant mosses, lack of costa in some leaves in species with normally costate leaves may occur either at branch bases, or near shoot tips, and also around gametangia. Kosjunia polyedra obviously represents the second case. Such a strong reduction is rare in extant plants and occurs mostly in anomalous cases (e.g. incompletely dryed Bryum spp., that remained for a certain time in wet warm envelopes, especially often 'sprouts up' into thin shoot ends with scaly leaves, similar to that in Fig. 1).

However, the presence of actively dividing cells in ecostate leaves (Fig. 16) indicates that this modification was rather a common stage of development, for if so, the costa in Protosphagnalean mosses appears to be more variable than in extant mosses of a similar size and structure, e.g. the Mniaceae.

Proximal branch leaves in attachment to branch base were illustrated by Malsova et al. (2012a: Fig. 69) for moss with Protosphagnalean cell dimorphism, but unidentifiable to genus (likely Vorcutannularia). Being only $100 \mu \mathrm{m}$ long, these leaves have an apparent costa. Therefore ecostate leaves in Figs. 10 and 16 can unlikely be treated as proximal ones.

The present material shows a rather homogeneous lamina cell areolation in leaves with a thin costa (cf. Kosjunia polyedra, Intia vicaria). At the same time in many leaves the end of a strong costa is 'submerged' in groups of actively dividing small cells (Figs. 18-20, 25-26), and this correlation requires an additional attention as it may disclose a regulation pattern different from modern mosses.

The descriptions of fossil mosses often involve characters without special study of their variation in the course of plant development. A possible decision for shortly costate leaves as in Figs. 6-7 could be their segregation in a separate genus, rather than attribution to Kosjunia, which also was never considered a plant with Protosphagnumlike cell structure at leaf base (Fig. 9). Moreover, the real belonging of dispersed material can be challenged always. However we believe that the construction of leaf series of the particular species based on similar areolation pattern will approach us to understanding of variation in the Protosphagnalean mosses and will built a solid ground for their taxonomy.

\section{ACKNOWLEDGEMENTS}

We are grateful to Yu.V. Mosseichik for help in bulk maceration of the material, to A.B. Ivanova for correcting English. The work was partly supported by RFBR 12-04-3215 and 13-04-01592.

\section{LITERATURE CITED}

AMARAL, P.G.C., M. BERNARDES DE OLIVEIRA, F. RICARDIBRANCO \& J. BROUTIN 2004. Presencia de Bryopsida fértil en los niveles Westfalianos del subgrup Itararé, Cuenca de Paraná, Brasil. Tropical Bryology 25: 101-110.

ANDERSON, J.M. \& H.M. ANDERSON 1985. Palaeoflora of South Africa. Prodromus of South African Megafloras, Devonian to Lower Cre- taceous. - A.A. Balkema, Rotterdam, 423 pp., 226 pls.

ANDREWS, H.N.Jn. 1961. Studies in paleobotany. - New York \& London: John Wiley \& Sons, 487 pp.

CHANDRA, S. 1995. Bryophytic remains from the early Permian sediments of India. - Palaeobotanist 43(2): 16-48.

CHRISITANO DE SOUZA, I.C., F. S. RICARDI BRANCO \& Y. LEON VARGAS 2012. Permian bryophytes of western Gondwanaland from the Parana' Basin in Brasil. - Palaeontology 55(1): 229-241.

DARRAH, W.C. 1960. Principles of palaeobotany. - New York: Ronald Press Cp., VII+295 pp.

[FEFILOVA, L.A.] ФЕФИЛОВА Л.А. 1978. Листостебельные мхи перми Европейского Севера СССР. - [Permian mosses of European North of USSR] Л., Наука [Leningrad, Nauka],120 pp.

FREY, W. \& M. STECH 2009. Bryophyta (Musci, mosses). - In: W. Frey (ed.), Syllabus of plant families A. Engler's Syllabus der Pflanzenfamilien. Part 3. Bryophytes and seedless vascular plants. 13th ed., 116-257. Gebr. Borntraeger Verlagsbuchhandlung, Stuttgart.

FREY, W. 1970 [1971]. Blattentwicklung bei Laubmoosen. - Nova Hedwigia 20: 463-556.

[GOMANKOV, A.V. \& S.V. MEYЕN] ГОМАНЬКОВ А.В., C.В. МЕЙЕН 1987. Татариновая флора (состав и распространение в поздней перми Евразии). - [Tatarina flora (composition and distribution in the Late Permian of Eurasia)] Tруды геол. ин-та АH CCCP [Trudy Geol. Inst. Akad.Nauk SSSR] 401: 1-174.

GOFFINET, B., W.R. BUCK \& A. J. SHAW 2009.Morphology, anatomy, and classification of the Bryophyta. - In: Goffinet, B. \& A. J. Shaw (eds.) Bryophyte Biology, $2 d$ ed. Cambridge University Press: Cambridge: $55-138$

IGNATOV, M. S. (1990) Upper Permian mosses from the Russia Platform. - Palaeontographica Abt. B, 217: 147-189 + Pl. 1-9.

[IGNATOV, M.S.] Игнатов М.C. 2013. Мхи палеозоя и мезозоя (обзор). - [Mosses of Paleozoic and Mesozoic, a review] Палеоботанический временник, приложение кжурналу Lethaea rossica [Palaeobotanichesky Vrenennik, suppl. of Lethaea rossica] 1: 29-40.

IGNATOV, M.S. \& D.E. SHCHERBAKOV 2009. A new fossil moss from the Lower Permian of the Russian Far East. - Arctoa 18: 201-212.

LACEY, W.S., D.E. VAN DIJK, \& K.D. GORDON-GRAY 1975. Fossils plants from the Upper Permian in the Mooi River district of Natal, South Africa. - Annals Natal Museum 2: 349-420.

LIU, L.J, \& Z.Q. YAO 1996. Early Late Permian Angara flora from Turpan-Hami Basin. - Acta Palaeontologica Sinice 35(6): 644-671 (in Chinese, English summary).

MASLOVA, E.V. Y.V. MOSSEICHIK, I.A. IGNATIEV, O.V. IVANOV \& M.S. IGNATOV 2012a. On the leaf development in Palaeozoic mosses of the order Protosphagnales. - Arctoa 21: 241-264.

MASLOVA, E.V., O.V. IVANOV \& M.S. IGNATOV 2012b. On differentiation of two species of Palaeozoic moss Intia (Protosphagnales). Arctoa 21: 237-240.

[NEUBURG, M.F.] НЕЙБУРГ М.Ф. 1960. Листостебельные мхи из перских отложений Ангариды. - [Mosses from the Permian of Angaraland] Труды ГИН АН СССР [Trudy Geologicheskogo Instituta Akademii Nauk SSSR] 19: 1-104 + $78 \mathrm{pl}$.

OTTONE, E.G. \& S. ARCHANGELSKY 2001. A new bryophyte from the Upper Carboniferous of Argentina. - Ameghiniana 38: 219-223.

[PUKHONTO, S.K.] ПУХOHTO C.К. 1998. Пермская стратиграфия и флора угольных отложений Печерского бассейна. - [Permian stratigraphy and flora of coal deposits of the Pechora Basin]. M., Научный Мир [Moscow, Nauchny Mir], 312 pp.

RENAULD, B. \& R. ZEILLER 1888. Études sur les terrain houiller de Commentry. Livre deuxième. Flore fossile.-Imprimateur Théolier and Cie, St. Étienne, 366 pp.

SMOOT, E.L. \& T.N. TAYLOR 1986. Structurally preserved fossil plants from Antarctica. II. A Permian moss from the Transantarctic Mountains. - American J. Bot. 73: 1683-1691.

THOMAS, B.A. 1972. A probable moss from the Lower Carboniferous of the Forest of Dean, Gloucestershire. - Ann. Bot. 36: 155-161. 